\title{
Co-eruptive deformation and dome growth during the 2008-2009 Chaitén eruption, Southern Andes
}

\author{
Mirella Piña-Gauthier ${ }^{1,4},{ }^{*}$ Luis E. Lara ${ }^{2}$, Klaus Bataille ${ }^{1}$, Andrés Tassara ${ }^{1}$, Juan C. Báez ${ }^{3}$

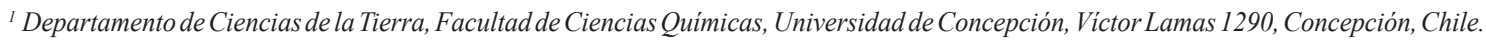 \\ mimepina@gmail.com; bataille@udec.cl; andrestassara@udec.cl \\ ${ }^{2}$ Servicio Nacional de Geología y Minería, Programa de Riesgo Volcánico, Avda. Santa María 0104, Santiago, Chile. \\ luis.lara@sernageomin.cl \\ ${ }^{3}$ Departamento de Ciencias Geodésicas y Geomática, Universidad de Concepción, J.A. Coloma 0201, Los Ángeles, Chile. \\ jbaez@udec.cl \\ ${ }^{4}$ Present adress: Compañia Minera Las Cenizas, Lota 2257, Santiago, Chile. \\ *corresponding author: luis.lara@sernageomin.cl
}

\begin{abstract}
GPS data from stations around the Chaitén Volcano show a co-eruptive pattern of inflation and deflation that correlates well with the estimated effusion rate during the 2008-2009 eruption. Axisymmetric radial deflation is coeval with periods of fast dome growth and inflation is coeval with periods of mostly endogenous dome growth at lower rates. Non-volcanic basement appears to be involved in the ground deformation as was inferred previously from InSAR observations. Data are insufficient to conduct full source modeling, but simple models are compatible with those that are based on petrological and geophysical observations. These results suggest a strong coupling between the eruption dynamics and response of the surrounding basement, which was probably conditioned by its structural fabric and crustal tectonics.
\end{abstract}

Keywords: Co-eruptive deformation, GPS, Deflation and inflation, Dome growth, Chaitén Volcano.

RESUMEN. Deformación co-eruptiva y crecimiento del domo durante la erupción 2008-2009 del volcán Chaitén, Andes del Sur. Datos GPS de estaciones ubicadas alrededor del volcán Chaitén muestran un patrón co-eruptivo de inflación y subsidencia que se correlaciona con la tasa de efusión estimada durante la erupción 2008-2009. La subsidencia radial asimétrica es contemporánea con períodos de rápido crecimiento del domo y la inflación con aquellos de crecimiento lento principalmente endógeno. El basamento no volcánico aparece involucrado en la deformación como se había inferido antes a partir de observaciones de interferometría radar. Los datos no son suficientes para una modelación bien constreñida de la fuente, pero algunos modelos simples resultan compatibles con aquellos propuestos a partir de argumentos petrológicos y la interferomería radar. Estos resultados muestran un fuerte acoplamiento entre la dinámica eruptiva y el basamento circundante, posiblemente condicionado por su fábrica estructural y la tectónica de la corteza. 


\section{Introduction}

In tectonically active regions volcanic unrest may be dynamically coupled with crustal tectonics. For example, Aeolian volcanoes showed signs of unrest after the Palermo Mw 5.9 earthquake in 2002 (Walter et al., 2009). Some years before in 1999, Cerro Negro Volcano, Nicaragua, erupted after a Mw 5.2 earthquake occurred in the near field (La Femina et al., 2004). The Southern Andes are regarded as an archetypical orogen where active tectonics and volcanic activity appear to be linked (López-Escobar et al., 1995; Rosenau et al., 2006; Cembrano and Lara, 2009). Nostro et al. (1998) and references therein provided an extensive review of the two-way coupling between crustal tectonics and volcanic activity, whereas Cembrano and Lara (2009) proposed different long-term volcano-tectonic associations for the Southern Andes as evidence of such a link. This genetic connection between crustal tectonics and volcanism in Southern Andes is mostly related to presence of the Liquiñe-Ofqui Fault Zone (LOFZ), a long-lived intra-arc fault system running from Copahue Volcano at $38^{\circ} \mathrm{S}$ to the Golfo de Penas at $47^{\circ} \mathrm{S}$ (Cembrano et al., 1996). Thus, plumbing systems and magma reservoirs seem to be coupled with their surrounding country rock; hence, deformation of basement rock could be a fundamental process that occurs before and after an eruption owing to volcanically induced pressure changes.

Although no instrumental data were gathered before the onset of the Chaiten eruption in May 2008, remote sensing data permitted analysis of deformation that clearly involved the basement. Wicks et al. (2011) modeled a complex basementembedded source to account for surface deformation measured from radar interferometry. Moreover, the main reservoir was inferred to be a collapsing sill nested on a crustal fault, which could be related to a pop-up structure of the LOFZ. Here we use shortterm velocities recorded by a small GPS network deployed shortly after the onset of the eruption in order to describe deformation that accompanied the eruptive cycle.

\section{Tectonic setting and crustal deformation}

Crustal deformation along the arc domain at this latitude $\left(39^{\circ} \mathrm{S}-46^{\circ} \mathrm{S}\right)$ is mostly related to the LOFZ, a 1,200-km-long intra-arc fault system (Cembrano et al., 1996). Although mostly known as a dextral strike-slip fault, recent studies have demonstrated a more complex kinematics of partitioned transtension and transpression over the last $25 \mathrm{~m}$.y. (Cembrano et al., 2000; Folguera et al., 2004; Rosenau et $a l ., 2006)$. Ductile deformation as young as ca. $3.5 \mathrm{Ma}$ is overprinted by widespread brittle deformation (Arancibia et al., 1999; Cembrano et al., 2000). Kinematic analysis of fault-slip data documents a long-term, NE-trending maximum horizontal compression, consistent with the shortterm instantaneous compression indicated by focal mechanisms of some shallow crustal earthquakes along the fault zone (e.g., Barrientos and Acevedo, 1992; Legrand et al., 2011). This kind of earthquake occurred close to the Aysén fjord (Fig. 1) in April 2007 during a $c a .90$ day seismic swarm along the master fault of the LOFZ (Legrand et al., 2011).

A causal relationship between volcanic processes and crustal tectonics has been invoked for the long-term evolution of Southern Andes (Cembrano and Lara, 2009 and references therein). In fact, PleistoceneHolocene stratovolcanoes and minor eruptive centers within the LOFZ are roughly organized into NW-, NS-NNE- and NE-trending alignments at a regional scale. The NW-trending volcanic alignments consist mostly of stratovolcanoes controlled by deep-seated, long-lived basement structures. NS-NNE aligments are typically clusters of small, symmetric Holocene pyroclastic cones sitting on top of the LOFZ master faults. In contrast, the NE-trending clusters of volcanic vents, minor eruptive centers and stratovolcanoes are associated with 'en échelon' tension fracture arrays, compatible with the long- and short-term NE-trending maximum horizontal stress axis. Chaitén Volcano lies in an apparent stepover of the LOFZ (Fig. 1) although crustal seismicity below the volcano depicts a NW-trending left lateral faulting as described by Lange et al. (2008).

\section{Geology of the Chaitén Volcano and local structure}

Chaitén Volcano $\left(42.8^{\circ} \mathrm{S} / 72.7^{\circ} \mathrm{W}\right)$ is a small, arc-front volcanic center located in the Southern Andean Volcanic Zone (SVZ: 33-46 ${ }^{\circ}$ S; Fig. 1). Poorly known in the context of the SVZ, it had been thought that the last eruption occurred at $c a .9 .4 \mathrm{ka}$ (Naranjo and Stern, 2004) in a caldera-forming eruption. However, growing evidence (e.g., Watt et al., 2009; Amigo et al., 2013, this volume; Watt 


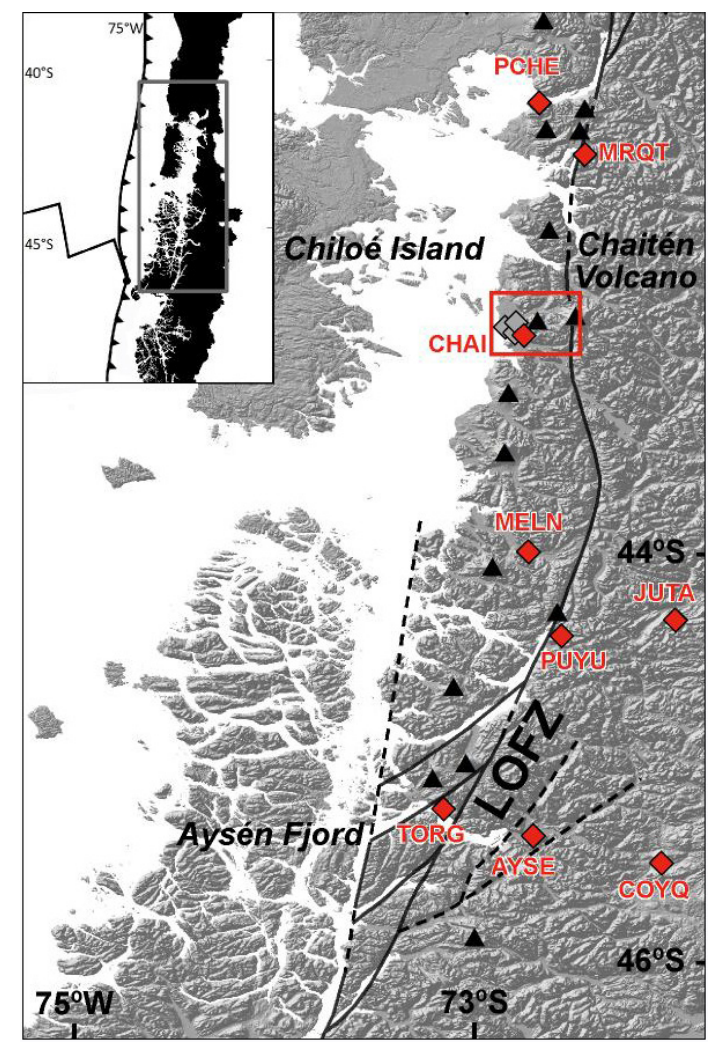

FIG. 1. Location map of volcanoes and major tectonic structures for a segment of the Southern Andes. Conspicuous morphological faults/lineaments are shown, notably the Liquiñe-Ofqui Fault Zone (LOFZ). Volcanoes are indicated by black triangles. Regional GPS stations are indicated by red diamonds and temporary (campaign) GPS stations are indicated by gray diamonds. Red box indicates area of figure 2 .

et al., 2013, this volume) suggests that products of some Holocene eruptions previously attributed to the neighboring Michinmahuida stratovolcano were sourced at Chaitén Volcano, and there is new evidence that historical eruptions have occurred (Lara et al., 2013, this volume). Based on a geological reconnaissance, two volcanic units have been defined (SERNAGEOMIN-BGRM, 1995): a Pleistocene, undifferentiated pre-caldera sequence, and a post-caldera rhyolitic dome. The latter was considered older than $5.6 \mathrm{ka}$ based on ages from archeological sites where obsidian tools have been found (Stern et al., 2002). The 3-km-wide caldera was in turn associated with an explosive event dated ca. 9.4 ka (Naranjo and Stern, 2004). The older volcanic pile rests on a basement formed by both Miocene granitoids and Paleozoic schists and gneises (SERNAGEOMIN-BRGM, 1995; Fig. 2).

Chaitén Volcano lies close to the the LOFZ main strand (Fig. 1). A plausible local setting is that it lies along a LOFZ-related pop-up structure similar to that depicted in other areas (e.g., Cembrano et al., 2002). Such a structure is consistent with structural data obtained from an east-dipping reverse fault found along the western boundary of this structure and along the master fault (Figs. 1, 2; Piña-Gauthier and Vega, 2010) ${ }^{1}$. Wicks et al. (2011) proposed this reverse fault as an effective path for magma migration during the short period of unrest that preceded the 2008 Chaitén eruption.

\section{Overview of the Chaitén Volcano and 2008- 2009 eruption}

On 2 May 2008 a large volcanic eruption began in the southern Andes without significant precursory activity (Carn et al., 2009). In fact, only 36 hours of seismic activity were recorded by distant instruments, located more than $300 \mathrm{~km}$ away from the Chaitén Volcano. On 30 April, some large volcano-tectonic (VT) earthquakes with coda magnitude up to 5 were located roughly at $20 \mathrm{~km}$ from Chaitén Volcano (Basualto et al., 2009). The number of large VT events reached up to 20 per hour on 2 May, coinciding with the first subplinian eruption which began approximately at 8:00 UTC (Lara, 2009; Major and Lara, 2013 , this volume). Seismicity declined abruptly by 3 May, but sustained ash emission continued until 8 May with several subplinian columns, the largest of which occurred on 6 May. The explosive phase of the eruption produced a total of $c a .0 .5-1 \mathrm{~km}^{3}$ (bulk volume) of rhyolitic tephra $\left(76 \% \mathrm{SiO}_{2}\right.$; Reich et al., 2009; Castro and Dingwell, 2009; Watt et al., 2009; Alfano et al., 2011).

Extrusion of a rhyolitic dome began on about 12 May (Major and Lara, 2013, this volume) although direct observation was not possible until 21 May. High but declining rates of dome growth $\left(>20 \mathrm{~m}^{3} / \mathrm{s}\right.$, even $c a .62 \mathrm{~m} / \mathrm{s}$ in some periods; Lara et al., 2009; Pallister et al., 2013, this volume) continued through

${ }^{1}$ Piña-Gauthier, M.; Vega, M. 2010. Caracterización geológica y geofísica del basamento del Complejo Volcánico Chaitén Michinmahuida. Report (Unpublished), Sernageomin: $40 \mathrm{p}$. 


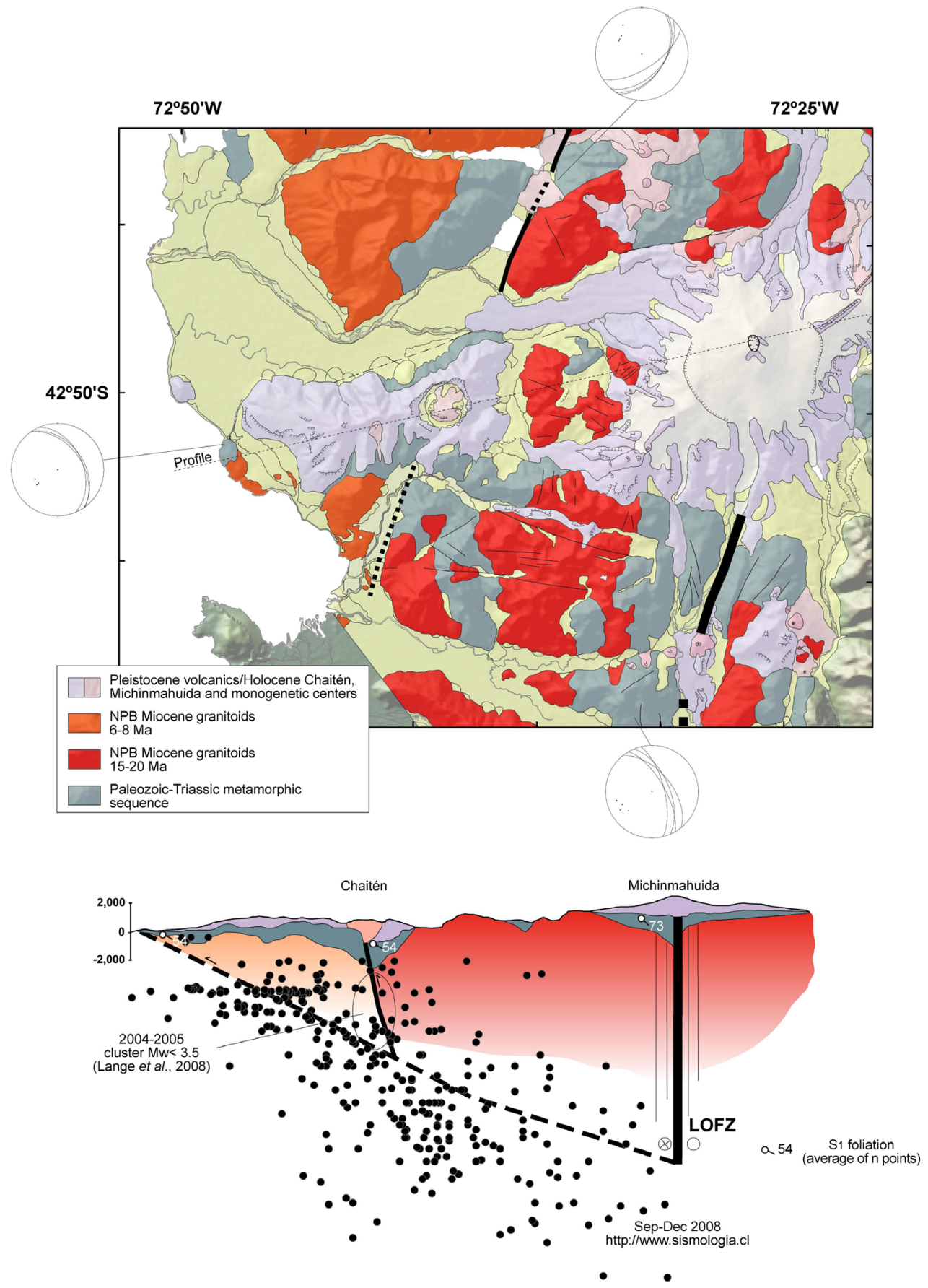

FIG. 2. Geological map of the basement in the vicinity of Chaitén Volcano (modified from SERNAGEOMIN-BRGM, 1995). Main strand of the Liquiñe-Ofqui Fault Zone (LOFZ) is indicated (solid line) along with the most prominent splay faults (dashed and dash-solid lines). The profile shows the pop-up structure that characterizes this megafault. Inferred east-dipping splay as proposed by Wicks et al. (2011) for the 'reservoir' according to InSAR modeling. Note the trace roughly coincides with the cluster of seismicity reported by the Servicio Sismológico Chileno (http://www.sismologia.cl), here shown only for NovemberDecember 2008. A secondary NE-dipping splay seems to have a morphological expression as both an eroded fault scarp (lineament) and a geological boundary. A cluster of crustal $\mathrm{Mw}<5$ earthquakes in 2004-2005 roughly depicts this fault (Lange et al., 2008). S1 foliation is also indicated to emphasize the structural fabric of the underlying basement. 
September 2008, accompanied by low ash columns $(<3.5 \mathrm{~km}$ altitude) and steam emissions. Dome extrusion was accompanied by weak (magnitude $<3$ ) but sustained seismicity with a new swarm of VT earthquakes that began in late June and continued through July. Random ash emissions occurred in July and August but as part of a long-term declining trend. By September 2008, seismicity waned, ash columns were no higher than $2 \mathrm{~km}$, and the rate of dome growth was negligible (Pallister et al., 2013, this volume). From October 2008 to February 2009 , the volcano entered a renewed phase of dome growth, which included a phase of spine extrusion and vigorous endogenous growth. Minor rock-falls were common from December 2008 to January 2009. On 19 February 2009, collapse of the SW flank of the dome formed a 'block-and-ash flow' that partly filled the moat of the caldera and also ran out along the Chaitén River valley for more than $7 \mathrm{~km}$. A bulk volume of $c a .0 .001-0.01 \mathrm{~km}^{3}$ was estimated for the deposit along the river valley, which represented only about $10 \%$ of the total failure volume (Major et al., 2013, this volume). After this episode of dome collapse, seismicity declined and little eruptive activity was reported. In March 2010 the red code alert was reduced to yellow. Total volume of the extruded rhyolitic lava was $c a .0 .8 \mathrm{~km}^{3}$ (Lara et al., 2009; Pallister et al., 2013, this volume).

\section{Pre-eruptive to co-eruptive deformation}

\subsection{GPS network and data processing}

Only a sparse GPS network was installed in the Chiloé and Aysén regions before the onset of the Chaitén eruption in 2008 (Fig.1). Campaign surveys, however, recorded a $6.5 \mathrm{~mm} / \mathrm{yr}$ steady motion (right lateral) of the LOFZ during the past decade (Wang et al., 2007). Because of the 2007 seismic swarm in the Aysén Fjord farther south (Legrand et al., 2011), 10 new stations were deployed and continuous GPS measurements were obtained along the $43^{\circ}-46^{\circ} \mathrm{S}$ segment (Báez and Bataille, 2009). As part of this effort, four additional stations were installed around Chaitén Volcano after the onset of the eruption: one permanent station installed in July 2008 (CHAI, Fig. 1) and three temporary stations, with two repeated sessions of measurement (each one with 48 hours of observation), deployed between April and June 2009 (Fig.1). Thus, the pre-eruptive period was covered only by distant stations. These remote stations showed subtle signatures of increased vertical displacement at the onset of the eruption (Piña-Gauthier et al., 2009), but those signals cannot be directly linked with the precursory activity.

A Trimble NetRS was used for the permanent station (CHAI, Fig. 1) and Trimble 4000 SSE stations for campaign surveys. Data collected were processed using Bernese Software 5.0 (Dach et al., 2007). In this process 10 regional stations of the IGS network were included. Precise orbit and Earth rotation parameters were used from IGS final products (Dow et al., 2009). During the processing, the antenna phase center was reduced using absolute calibration, and double differences were modeled in L3 using elevation masks of $15^{\circ}$, owing to the configurations of mountains and a sampling rate of 30 seconds. To form the single differences, a phase strategy of maximum observations was used (OBS_MAX). No a priori troposphere model was applied. The troposphere parameters were estimated in all steps of parameter estimation. For the datum definition we used a minimum constraint approach, applying the No Net Rotation (NNR) and No Net Translation (NNT) conditions for a group of selected reference stations. Coordinates for each reference station were obtained from the global polyhedron weekly solution (Dow et al., 2009). Our results are compatible with ITRF2005 (Altamimi et al., 2007). Finally, horizontal and vertical displacements were estimated on a daily basis only for the permanent station (Fig. 3). Ground deformation is reported here in terms of velocity or cumulative displacement.

GPS time series such as we obtained for the permanent station can be modeled using a wide range of statistical tools. Special attention must be paid to the scattering or 'noise', which could lead to an incorrect calculation of strain rates (e.g., Li et al., 2000). However, considering the short time frame and the qualitative approach we have taken here, time series analysis was performed only for the vertical component using a simple approach (Fig. 4). First, residuals were obtained from a linear regression over the entire dataset. The distribution of residuals (assumed to be normal) was used to identify possible outliers which were rejected using the Chauvenet's criterion (e.g., Taylor, 1997). Linear regression by least squares was performed over the corrected dataset in order to obtain the average velocity and its uncertainty for each time window. Time windows 

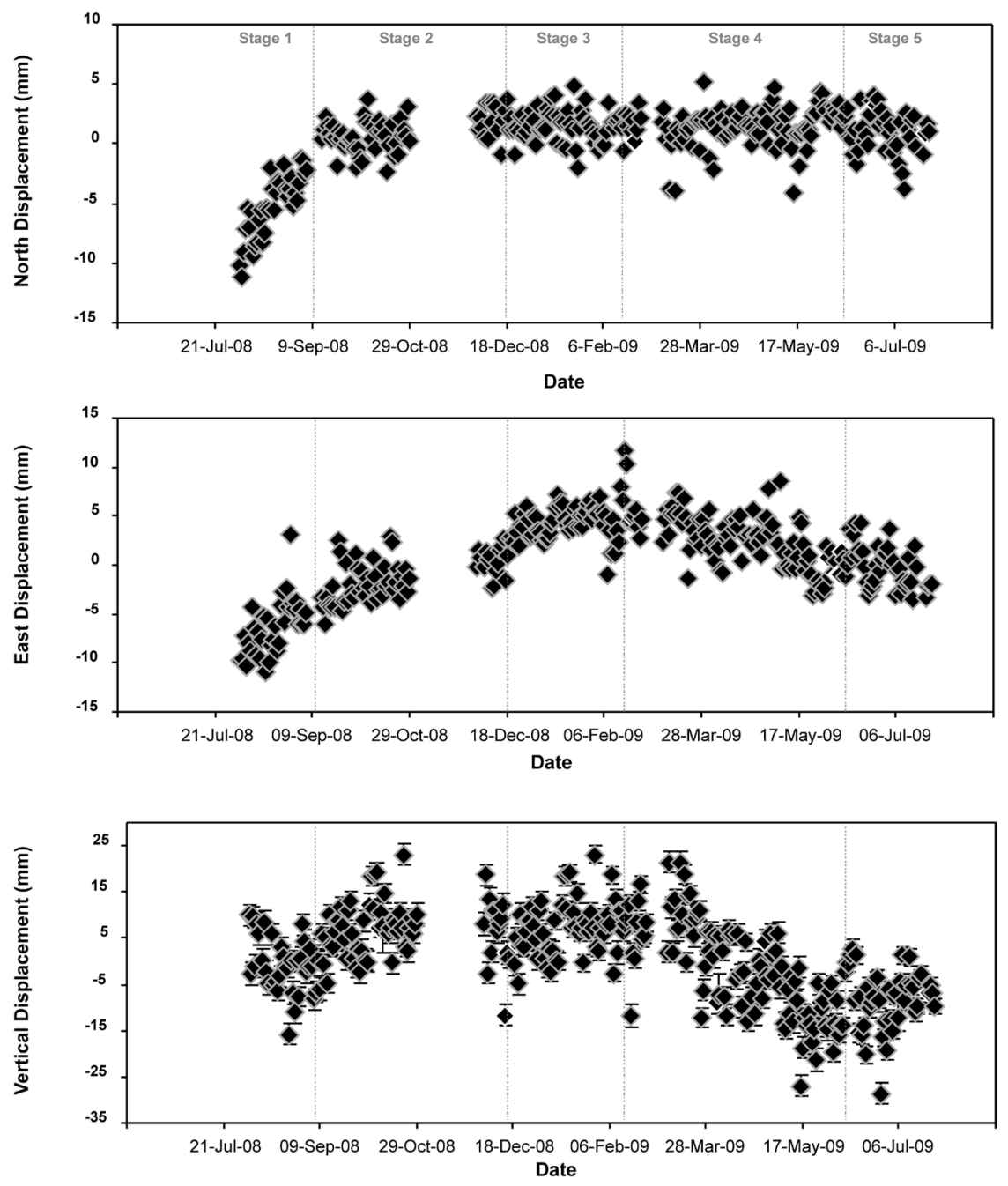

FIG. 3. Time series of displacement components for the station CHAI, located $10 \mathrm{~km}$ west of the active vent atop the crystalline basement. Uncertainty at $2 \sigma$ level is indicated only for the vertical component. Horizontal components have an average uncertainty below $2.36 \mathrm{~cm} / \mathrm{yr}$ and are not represented. Linear regression was performed for each distinct stage of displacement in order to obtain velocities for these time windows (see Table 1). The most unambiguous variation is observed in the vertical component, which allows definition of five stages in terms of the co-eruptive ground deformation.

were defined by visual inspection and correspond to natural breaks of the time series, supported by basic statistics. Goodness of fit is generally poor because of the scattering but acceptable for stages 1 and 4 (Table 1).

\subsection{Pre-eruptive ground deformation}

Four years before the eruption, a cluster of seismicity around Chaitén Volcano was detected by a temporary seismic network (Lange et al., 2008;
Fig. 2). Crustal events up to Mw 3.6 were recorded with two double-couple focal mechanisms that can be interpreted as strike-slip faulting along NWtrending vertical structures rooted on the basement (Lange et al., 2008).

Distant GPS stations along the LOFZ appear to show subtle breaks in the vertical component of displacement at the onset of the eruption (Piña-Gauthier et al., 2009). However, no systematic patterns of precursory deformation which could be related to inflation during the short buildup to the eruption 

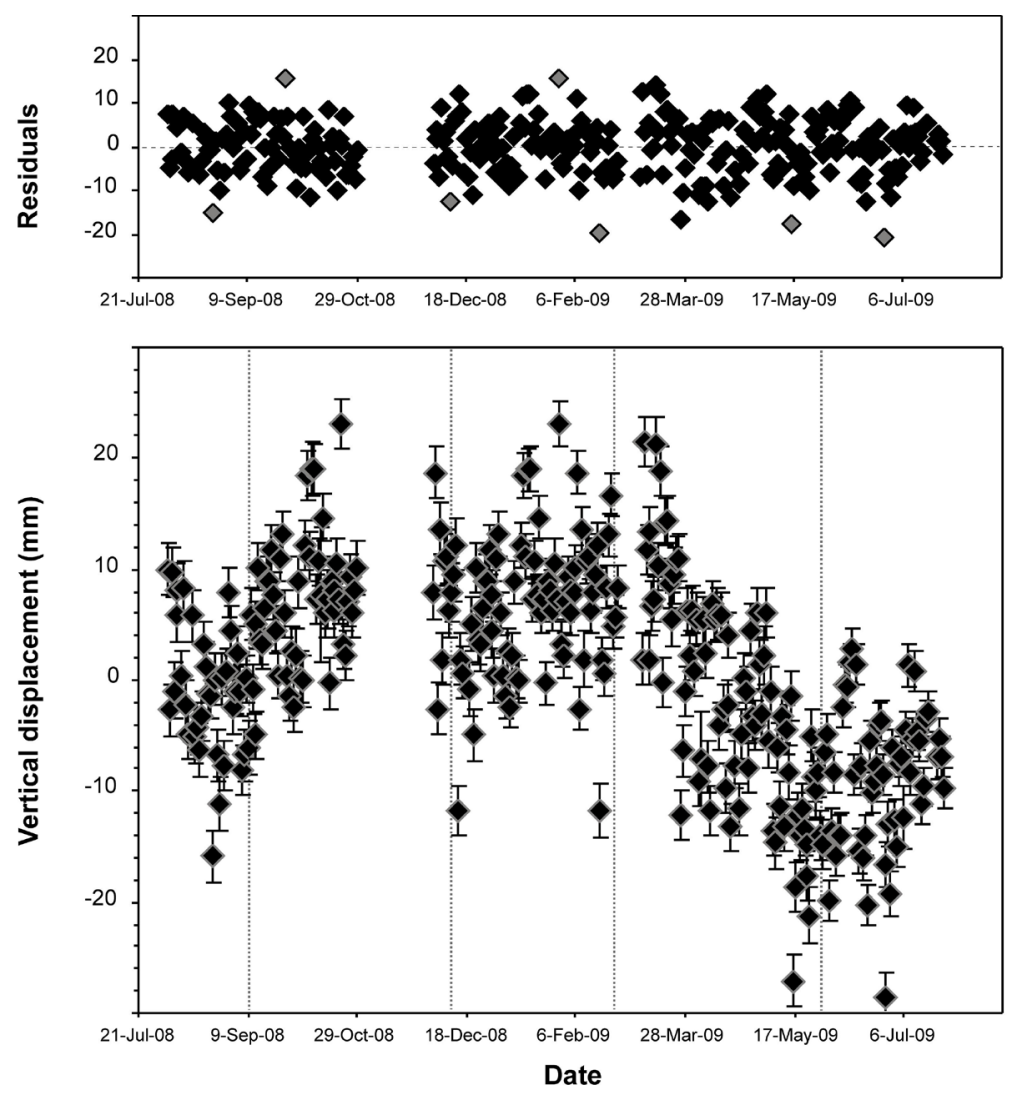

FIG. 4. Modified time series for the vertical component of displacement at station CHAI, after removal of outliers. Upper panel shows a plot for residuals used to define possible outliers (gray diamonds) in the uncorrected dataset (see text for details). Regression by least squares was applied to the corrected time series (lower panel) for each time window in order to obtain velocities and related uncertainties at the $2 \sigma$ level reported in Table 1 .

are observed in the data from the closest station. On the other hand, no deformation was detectable in a limited number of ERS interferograms between 1993-1998 (e.g., Pritchard and Simons, 2004, with data restricted to the summit caldera) or by ALOS interferometry between April 2007 and 16 April 2008 (Fournier et al., 2010). Lack of detection of deformation during these periods suggests that any precursory deformation was minor or that it occurred less than 2 weeks before the eruption.

\subsection{Co-eruptive ground deformation}

\subsubsection{Published data based on InSAR}

Co-eruptive ground deformation in terms of vertical displacement (up to $50 \mathrm{~cm}$ from the satellite line of sight) is observed in descending mode ALOS interferograms between November 2007 and February
2010 (Wicks et al., 2011). These authors propose a three-component source model accounting for both the observed deformation and two centroid moment solutions (Global CMT Project at http:// www.globalcmt.org) at the beginning of the eruption. Building on a previous hypothesis (e.g., Lara et al., 2008), Wicks et al. (2011) suggested that diking, and hence crustal tectonics, played a key role in the rapid onset of the eruption. In this model, three bodies (a deep NE-dipping sill or reservoir, a near vertical NE-trending dike and a narrow, vertical lathlike conduit) account for the observed deformation. Deformation of the NE-dipping sill was responsible for most of the signal.

\subsubsection{Deformation based on GPS data}

The most complete GPS time series can be retrieved from the CHAI station, which was installed in 
TABLE 1. SUMMARY OF GPS DATA FOR CHAITÉN 2008-2009 ERUPTION.

\begin{tabular}{|c|c|c|c|c|c|c|c|}
\hline & & 2008 & 2008 & 2008 & 2009 & 2009 & \\
\hline Veloc & & $\begin{array}{c}\text { Stage 1 } \\
\text { (2Jul-9Sep) }\end{array}$ & $\begin{array}{c}\text { Stage 2 } \\
\text { (10Sep-18Dec) }\end{array}$ & $\begin{array}{c}\text { Stage 3 } \\
\text { (18Dec-19Feb) }\end{array}$ & $\begin{array}{c}\text { Stage } 4 \\
\text { (20Feb-7Jun) }\end{array}$ & $\begin{array}{c}\text { Stage } 5 \\
\text { (8Jun-24Jul) }\end{array}$ & $\begin{array}{l}\text { Radial distance } \\
\text { to source }(\mathrm{km})\end{array}$ \\
\hline Perman & & & & & & & \\
\hline CHAI & Vert & $\begin{array}{c}-5.75 \pm 2.79 \\
\left(\mathrm{R}^{2}=0.11\right)\end{array}$ & $\begin{array}{l}2.42 \pm 0.83 \\
\left(\mathrm{R}^{2}=0.12\right)\end{array}$ & $\begin{array}{l}1.89 \pm 1.41 \\
\left(\mathrm{R}^{2}=0.03\right)\end{array}$ & $\begin{array}{c}-9.46 \pm 0.81 \\
\left(\mathrm{R}^{2}=0.59\right)\end{array}$ & $\begin{array}{c}-0.65 \pm 2.43 \\
\left(\mathrm{R}^{2}=0.01\right)\end{array}$ & -10.0 \\
\hline & $\mathrm{Hz}$ & $\begin{array}{l}9.74 \pm 1.66 \\
\left(\mathrm{R}^{2}=0.37\right)\end{array}$ & $\begin{array}{l}1.53 \pm 0.37 \\
\left(\mathrm{R}^{2}=0.23\right)\end{array}$ & $\begin{array}{l}1.21 \pm 0.59 \\
\left(\mathrm{R}^{2}=0.04\right)\end{array}$ & $\begin{array}{l}1.52 \pm 0.21 \\
\left(\mathrm{R}^{2}=0.12\right)\end{array}$ & $\begin{array}{c}-1.80 \pm 0.53 \\
\left(\mathrm{R}^{2}=0.18\right)\end{array}$ & - \\
\hline Campai & & & & & & & \\
\hline CAMA & Vert & - & - & - & 51.05 & - & -7.8 \\
\hline & $\mathrm{Hz}$ & - & - & - & -2.29 & - & - \\
\hline STBA & Vert & - & - & - & 0.03 & - & -11.9 \\
\hline & $\mathrm{Hz}$ & - & - & - & 1.19 & - & - \\
\hline FAND & Vert & - & - & - & 3.10 & - & -9.5 \\
\hline & $\mathrm{Hz}$ & - & - & - & 224.80 & - & - \\
\hline Deform & ime & deflation & weak inflation & weak inflation & deflation & steady & - \\
\hline
\end{tabular}

Values obtained by least squares regression (see text for details). Positive sign for upward vertical displacement, and for north and eastward horizontal displacement. Goodness of fit is shown in parenthesis as $\mathrm{R}^{2}$, the linear correlation coefficient (only reported for the permanent station CHAI). Deformation regime is defined qualitatively in terms of the vertical component at CHAI station.

July 2008, two months after the onset of the eruption (Figs. 3, 4). This station recorded deformation during and subsequent to the period of rapid growth of the new dome complex (Lara et al., 2009; Pallister et al., 2013, this volume). Three other GPS stations (FAND, STBA, CAMA; Fig. 5) were installed in April 2009. Those stations recorded mostly the waning stage of the eruption. All stations were installed on the western and northern sides of Chaitén Volcano, the only places accessible during the period of most intense eruptive activity.

Daily horizontal and vertical displacements at station CHAI from July 2008 to July 2009 reached up to $\sim 14 \mathrm{~mm}$ and $\sim 20 \mathrm{~mm}$, respectively (Fig 3). Shortly after the onset of the eruption the horizontal velocity (Table 1) was even one order of magnitude greater than the long-term, background transport of the forearc sliver controlled by the LOFZ (Wang et al., 2007; Piña-Gauthier et al., 2009; Báez and Bataille, 2009). Distinct variations of the time series are clear for each displacement component at station CHAI (Fig. 3, 4). Stage 1 corresponds to the phase of exogenous lava flow described by Pallister et al. (2013, this volume) when the highest growth rates were observed. Stages 2 and 3 correspond to the phase of spine extrusion, accompanied by endogenous dome growth (Bernstein et al., 2013, this volume; Pallister et al., 2013, this volume). Stage 4 corresponds to a phase of mostly endogenous dome growth (Pallister et al., 2013, this volume), and stage 5 is the clearly defined waning stage of the eruption. From May to September 2008, average horizontal displacement strikes NE (Fig. 5), and the vertical component of displacement depicts a high rate of subsidence (-5.75 $\pm 2.79 \mathrm{~cm} / \mathrm{yr}$; Table 1; Figs. 3, 4). This period was characterized by a high rate of magma discharge; the dome was growing at $>30 \mathrm{~m}^{3} / \mathrm{sec}$ during May to July 2008 with a peak $>60 \mathrm{~m}^{3} / \mathrm{sec}$ in the first weeks of dome growth (Lara, 2009; Lara et al., 2009; Pallister et al., 2013, this volume). From September to December 2008, the rate of NE horizontal displacement declined, but the rate of vertical displacement increased to $2.42 \pm 0.83 \mathrm{~cm} / \mathrm{yr}$ (inflation). Dome growth was negligible in September 2008 , but a subsequent renewal of growth is evident from emergence of a prominent spine accompanied 


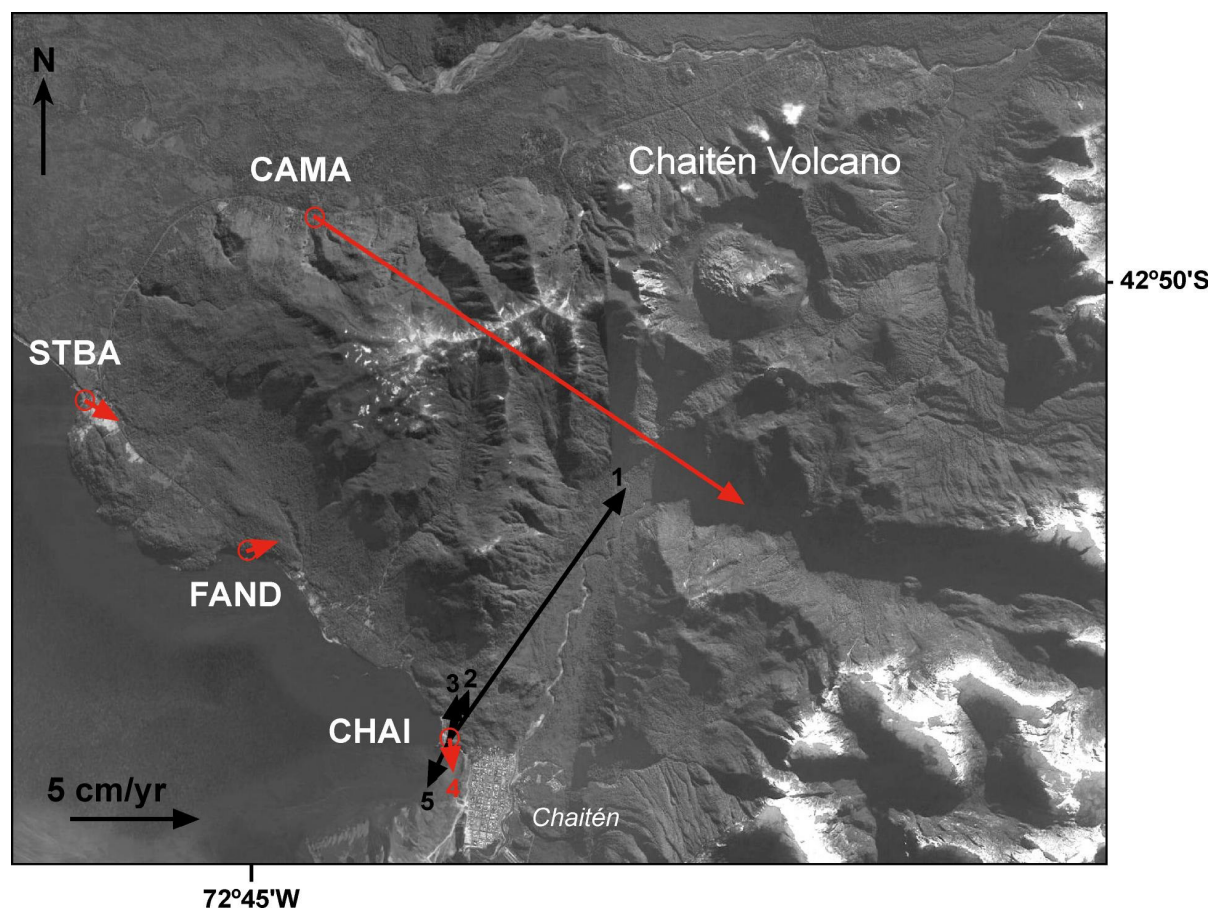

FIG 5. Velocity vectors as computed for the local GPS stations at Chaitén Volcano. Small circles report uncertainty at the $2 \sigma$ level. Red arrows are for coeval measurements in 2009, which correspond to stage 4 (see Table 1 for details). Correlative numbers refer to these stages (see text for details). Note the roughly radial but asymmetric pattern of horizontal velocity.

by endogenous growth (Bernstein et al., 2013, this volume; Pallister et al., 2013, this volume). By September 2008, the extruded volume of lava was $c a$. $0.5 \mathrm{~km}^{3}$ and it accumulated at rates at $c a .15 \mathrm{~m}^{3} / \mathrm{sec}$ toward the end of this period. A minor but progressive increase in the vertical component of displacement $(1.89 \pm 1.41 \mathrm{~cm} / \mathrm{yr})$ is observed until 19 February 2009, when a large collapse occurred at the dome complex (Major et al., 2013, this volume; Pallister et al., 2013, this volume). Repeated explosions, rock falls and a persistent high level of seismicity were observed at that time (Lara, 2009; Basualto et al., 2009). A remarkable change occurred after the dome collapse in February 2009, with horizontal displacement oriented toward the SSE and rapid subsidence of $-9.46 \pm 0.81 \mathrm{~cm} / \mathrm{yr}$ (Fig. 4). Subsidence is evident until early June 2009 (Fig. 4), at which time the three components of displacement at CHAI stabilized.

The three temporary GPS stations (Fig. 5) were installed for three months from April to June 2009, but the data are insufficient to display a time series. However, they do show a roughly radial pattern of horizontal displacement toward the volcano (Fig. 5), which is coeval with the sharp subsidence at CHAI in the same period. The waning stage of the eruption was also marked by a decreasing level of seismicity and spectral radiance (as reported by MODVOLC algorithm; Wright et al., 2004) at the dome complex (Fig.6).

\section{Discussion}

Surface deformation at volcanoes is thought to be a signal of both unrest and eruption processes. It is a function of several unknowns such as magma volume, physical properties of magma and country rocks, and tectonic setting. In particular, the role of basement structure and crustal faulting are poorly understood.

For the 2008-2009 eruption of Chaitén Volcano there is compelling evidence of basement involvement at large scale. In fact, early co-eruptive deformation was modeled with a reservoir nested along a NE-dipping plane (Wicks et al., 2011), which can be ascribed to a pop-up structure of the LOFZ (Fig. 2). Inflation 

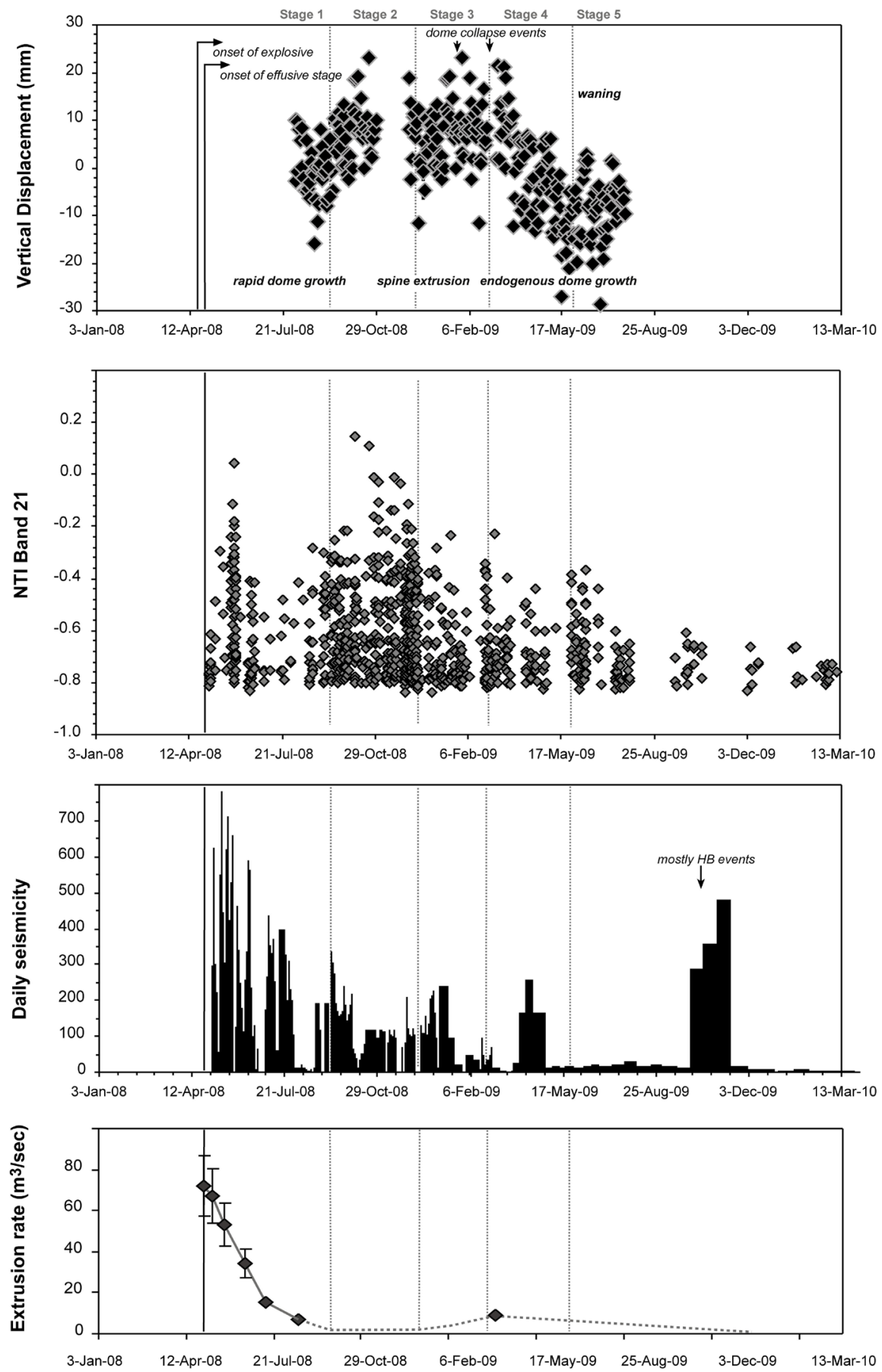

Date

FIG. 6. Complementary time series of various eruption data displayed for comparison with the vertical component of displacement measured at station CHAI. Spectral radiance is reported as NTI (Normalized Thermal Index) from the MODIS sensor through a $1 \mathrm{~km}$ pixel automatic detection algorithm (Wright et al., 2004; http://modis.higp.hawaii.edu/). Daily seismicity was compiled from the public reports released by SERNAGEOMIN (www.sernageomin.cl) and includes mostly events (VT/HB) with M>1. The cumulative extruded volume and resulting growth rates are from Pallister et al. (2013, this volume). 
and subsequent collapse of this sill-like magma body solved the observed InSAR signal at the beginning of the eruption. Our GPS data build upon this model and show that basement structures responded with uplift and subsidence which are well correlated with magma withdrawal and possible replenishment of the reservoir. Despite the poor spatial resolution of this analysis, a time series of displacement from the only permanent GPS station around Chaitén (CHAI) shows distinct phases that mimic those of the spectral radiance (a proxy for the surface temperature) and seismicity (Fig. 6). Moreover, patterns in the vertical component of surface displacement at CHAI correlate well with variations in the rate of lava effusion calculated for the eruption (Fig. 6). In fact, rapid downward displacement at the early stage of station deployment is coeval with the highest extrusion rate. Weak upward displacement corresponds to an unstable period of possible magma replenishment, which sustained a low rate of dome growth that culminated in a major collapse in February 2009. This collapse episode was followed by a period of renewed dome growth, which was also accompanied by subsidence of the basement (Figs. 3, 4). Final stabilization of the GPS signal in July 2009 coincides with a lack of significant thermal anomalies, a sharp decrease in seismicity, dominated at this time by shallow hybrid events (Basualto et al., 2009), intense gas steaming, and small, minor explosions.

Our data lack the spatial and temporal resolution required to fully characterize the geometry and magnitude of the volumetric expansion and contraction at the source. However, data from both permanent and temporary stations yield some insight. For instance, vertical displacement at CHAI can be correlated with the rate of lava effusion as determined from volumetric changes in the dome, and hence related to inflation and deflation at the source. Cyclic patterns of dome growth have been correlated with deformation data from GPS at Soufrière Hills Volcano, Montserrat, with deflation during periods of dome extrusion and inflation during times of quiescence (Mattioli et al., 1998; Wadge et al., 2006). At Chaitén Volcano, horizontal displacement is toward the vent during times of deflation and away from the vent during inflation. Temporary stations showed a roughly radial pattern of horizontal displacement, although contrasting magnitudes of displacement suggest a displacement gradient that is most probably related to complex geometry at the source and the pattern of magma migration (Fig. 5). Source geometry cannot be solved with our data, but simple source models can be tested. A single Mogi source (Mogi, 1958) or a dipping point crack (e.g., Davies, 1983) at $10 \mathrm{~km}$ depth with a radius of $c a$. $0.25-0.5 \mathrm{~km}$ could fit the GPS data. The latter source model is closer to the geometry inferred from InSAR modeling by Wicks et al. (2011), which may imply that magma intruded along the regional tectonic fabric and sheared splay faults of the LOFZ. Whatever the process at the source, the co-eruptive InSAR model (Wicks et al., 2011) is supported by our GPS data, and both sets of data describe patterns of inflation and deflation that correlate with other proxies of eruptive behavior.

\section{Conclusions}

Both permanent and campaign GPS stations installed around Chaitén Volcano recorded patterns of deformation that can be related to eruptive processes. Observed radial, but asymmetric, patterns of horizontal displacement are compatible with a dipping sill as the main magmatic source as inferred from InSAR modeling by Wicks et al. (2011). The vertical component of displacement at the continuous GPS station correlates well with estimated variations in extrusion rate (Pallister et al., 2013, this volume). That signal can be interpreted as reflecting inflation and deflation of the source at depth. Geometry of this source is poorly constrained, but it could be related to the basement structure controlled by the LOFZ.

\section{Acknowledgments}

Permanent GPS survey was supported by ONEMI and Universidad de Concepción. Campaign stations were installed in 2009 with support by the Programa de Riesgo Volcánico at SERNAGEOMIN. An additional campaign had partial funding from Fondecyt No.11070222 grant (L.E. Lara). Reviews by D. Dzurisin, M. Lisowski and special editor J.J. Major significantly improved this work. Geological study of the 2009 Chaitén eruption is a collaborative work between SERNAGEOMIN and the United States Geological Survey and is also part of a long-term research at SERNAGEOMIN.

\section{References}

Alfano, F.; Bonadonna, C.; Volentik, A.C.M.; Connor, C.B.; Watt, S.F.L.; Pyle, D.M.; Connor, L.J. 2011. 
Tephra stratigraphy and eruptive volume of the May, 2008, Chaitén eruption, Chile. Bulletin of Volcanology 73 (5): 613-630.

Altamimi, Z.; Collilieux, X.; Legrand, J.; Garayt, B.; Boucher, C. 2007. ITRF2005: A new release of the International Terrestrial Reference Frame based on time series of station position and Earth Orientation Parameters. Journal of Geophysical Research 112 (B09401). doi:10.1029/2007JB004949.

Amigo, A.; Lara, L.E.; Smith, V. 2013. Holocene record of large explosive eruptions from Chaitén and Michinmahuida Volcanoes, Chile. Andean Geology 40 (2): 227-248.

Arancibia, G.; Cembrano, J.; Lavenu, A. 1999. Transpresión dextral y partición de la deformación en la Zona de Falla Liquiñe-Ofqui, Aisén, Chile (44-45으). Revista Geológica de Chile 26 (1): 3-22.

Báez, J.C.; Bataille, K. 2009. Crustal velocities estimations during a short lived seismic swarm, recent activities estimated from continuous GPS observations. In International Association of Geodesy Symposia: Geodesy for Planet Earth, No. 136: p. 94. Buenos Aires.

Basualto, D.; Moreno, H.; Lara, L.E.; Peña, P.; Muñoz, J.; Delgado, C.; Gallegos, C. 2009. Actividad sísmica relacionada con la evolución de la erupción del volcán Chaitén durante el 2008, Andes del Sur. In Congreso Geológico Chileno, No. 12, CD Rom: S07-005.

Barrientos, S.; Acevedo, P. 1992. Seismological aspects of the 1988-1989 Lonquimay (Chile) volcanic eruption. Journal of Volcanology and Geothermal Research 53 (1-4): 73-87.

Bernstein, M.; Pavez, A.; Varley, N.; Whelley, P.; Calder, E. 2013. Rhyolite lava dome growth styles at Chaitén Volcano, Chile (2008-2009): Interpretation of thermal imagery. Andean Geology 40 (2): 295-309.

Castro, J.M.; Dingwell, D.B. 2009. Rapid ascent of rhyolitic magma at Chaitén Volcano, Chile. Nature 461: 780-783.

Carn, S.A.; Pallister, J.S.; Lara, L.E.; Ewert, J.W.; Watt, S.; Prata, A.J.; Thomas, R.J.; Villarosa, G. 2009. The unexpected awakening of Chaitén Volcano, Chile. Eos, Transactions American Geophysical Union 90 (24): 205-206. doi: 10.1029/2009EO240001.

Cembrano, J.; Lara, L. 2009. The link between volcanism and tectonics in the Southern Volcanic Zone of the Chilean Andes: A review. Tectonophysics 471: 96-113.

Cembrano, J.; Lavenu, A.; Reynolds, P.; Arancibia, G.; López, G.; Sanhueza, A. 2002. Late Cenozoic transpressional ductile deformation north of the Nazca-South America-Antarctica triple junction. Tectonophysics 354: 289-314.
Cembrano, J.; Schermer, E.; Lavenu, A.; Sanhueza, A.; 2000. Contrasting nature of deformation along an intra-arc shear zone, the Liquiñe-Ofqui Fault Zone, southern Chilean Andes. Tectonophysics 319: 129-149.

Cembrano, J.; Hervé, F.; Lavenu, A. 1996. The Liquiñe Ofqui Fault Zone: A long-lived intra-arc fault system in southern Chile. Tectonophysics 259: 55-66.

Dach, R.; Hugentobler, U.; Fridez, P.; Meindl, M. 2007. Bernese GPS Software Version 5.0. Astronomical Institute, University of Bern: 612 p.

Davis, P.M. 1983. Surface deformation associated with a dipping hydrofracture. Journal of Geophysical Research 88 (B7): 5826-5834.

Dow, J.M.; Neilan, R.E.; Rizos, C. 2009. The International GNSS Service in a changing landscape of Global Navigation Satellite Systems. Journal of Geodesy 83: 191-198.

Folguera, A.; Ramos, V.; Hermanns, R.L.; Naranjo, J. 2004. Neotectonics in the foothills of the southernmost central Andes $\left(37^{\circ}-38^{\circ} \mathrm{S}\right)$ : Evidence of strike-slip displacement along the Antiñir-Copahue fault zone. Tectonics 23 (5): 23 p. doi: 10.1029/2003TC001533.

Fournier, T.J.; Pritchard, M.E.; Riddick, S.N. 2010. Duration, magnitude, and frequency of subaerial volcano deformation events: New results from Latin America using InSAR and a global synthesis. Geochemistry, Geophysics, Geosystems 11 (1): 29 p. doi: 10.1029/2009GC002558.

La Femina, P.C.; Connor, C.B.; Hill, B.E.; Strauch, W.; Saballos, J.A. 2004. Magmatectonic interactions in Nicaragua: the 1999 seismic swarm and eruption of Cerro Negro Volcano. Journal of Volcanology and Geothermal Research 137: 187-99.

Lange, D.; Cembrano, J.; Rietbrock, A.; Haberland, C.; Dahm, T.; Bataille, K. 2008. First seismic record for intra-arc strike-slip tectonics along the LiquiñeOfqui Fault Zone at the obliquely convergent plate margin of the Southern Andes. Tectonophysics 455 (1-4): 14-24.

Lara, L.E. 2009. The 2008 eruption of the Chaitén Volcano, Chile: A preliminary report. Andean Geology 36 (1): 125-129.

Lara, L.E.; Moreno, R.; Amigo, A.; Hoblitt, R.P.; Pierson, T.C. 2013. Late Holocene history of Chaitén Volcano: New evidence for a $17^{\text {th }}$ century eruption. Andean Geology 40 (2): 249-261.

Lara, L.E.; Pallister, J.S.; Ewert, J.W. 2008. The 2008 eruption of Chaitén Volcano, Southern Chile: A tectonically controlled eruption. In Fall Meeting American Geophysical Union, Abstract V42C-02. 
Lara, L.E.; Valenzuela, C.; Basualto, D.; Pallister, J. 2009. Crecimiento excepcionalmente rápido del domo compuesto del volcán Chaitén 2008-2009. In Congreso Geológico Chileno, No. 12, CD Rom: S07-15. Santiago.

Legrand, D.; Barrientos, S.; Bataille, K.; Cembrano, J.; Pavez, A. 2011. The fluid-driven tectonic swarm of Aysén Fjord, Chile (2007) associated with two earthquakes ( $M w=6.1$ and $M w=6.2)$ within the Liquiñe-Ofqui Fault Zone. Continental Shelf Research 31: 154-161.

Li, J.; Miyashita, K.; Kato, T.; Miyazaki, S. 2000. GPS time series modeling by autoregressive moving average method: Application to the cristal deformation in central Japan. Earth Planets Space 52: 155-162.

López-Escobar, L.; Cembrano, J.; Moreno, H. 1995. Geochemistry and tectonics of the Chilean Southern Andes basaltic Quaternary volcanism (37-46 $\mathrm{S})$. Revista Geológica de Chile 22 (2): 219-234.

Major, J.J.; Lara, L.E. 2013. Overview of Chaitén Volcano, Chile, and its 2008-2009 eruption. Andean Geology 40 (2): 196-215.

Major, J.J.; Pierson, T.C.; Hoblitt, R.P.; Moreno, H. 2013. Pyroclastic density currents associated with the 2008-2009 eruption of Chaitén Volcano (Chile): Forest disturbances, deposits and dynamics. Andean Geology 40 (2): 324-358.

Mattioli, G.; Dixon, T.H.; Farina, F.F.; Howell, E.S.; Jansma, P.E.; Smith, A.L. 1998. GPS measurement of surface deformation around Soufrière Hills Volcano, Montserrat, from October 1995 to July 1996. Geophysical Research Letters 25 (18): 3417-3420.

Mogi, K. 1958. Relations between the eruptions of various volcanoes and the deformation of the ground surface around them. Bulletin of the Earthquake Research Institute 36: 99-134.

Naranjo, J.A.; Stern, C.R. 2004. Holocene tephrochronology of the southernmost part $\left(42^{\circ} 30^{\prime}-45^{\circ} \mathrm{S}\right)$ of the Andean Southern Volcanic Zone. Revista Geológica de Chile 31 (2): 225-240.

Nostro, C.; Stein, R.S.; Cocco, M.; Belardinelli, M.E.; Marzocchi, W. 1998. Two-way coupling between Vesuvius eruptions and southern Apennine earthquakes, Italy, by elastic stress transfer. Journal of Geophysical Research 103: 24487-24504.

Pallister, J.S.; Diefenbach, A.K.; Burton, W.C.; Muñoz, J.; Griswold, J.P.; Lara, L.E.; Lowerstern, J.B.; Valenzuela, C.E. 2013. The Chaitén rhyolite lava dome: Eruption sequence, lava dome volumes, rapid effusion rates and source of the rhyolite magma. Andean Geology 40 (2): 277-294.
Piña-Gauthier, M.; Bataille, K.; Lara, L.E.; Tassara, A.; Báez, J.C. 2009. Relación entre el Terremoto de Aysén (abril 2007) y la erupción en curso del volcán Chaitén mediante modelamiento de GPS: Resultados preliminares. In Congreso Geológico Chileno, No. 12, CD Rom: S9-70. Santiago.

Pritchard, M.E.; Simons, M. 2004. An InSAR-based survey of volcanic deformation in the southern Andes. Geophysical Research Letters 31 (15): 4 p. doi: 10.1029/2004GL020545.

Reich, M.; Zúñiga, A.; Amigo, Á.; Vargas, G.; Morata, D.; Palacios, C.; Parada, M.Á.; Garreaud, R.D. 2009. Formation of cristobalite nanofibers during explosive volcanic eruptions. Geology 37 (5): 435-438.

Rosenau, M.; Melnick, D.; Echtler, H. 2006. Kinematic constraints on intra-arc shear and strain partitioning in the Southern Andes between $38^{\circ} \mathrm{S}$ and $42^{\circ} \mathrm{S}$ latitude. Tectonics 25 (4): 13 p. doi:10.1029/2005TC001943.

SERNAGEOMIN-BRGM. 1995. Carta Metalogénica X región Sur. Servicio Nacional de Geología y Minería -Bureau de Recherches Géologiques et Minières, Informe Registrado IR-95-05, 4 Tomos, 10 Vols., 95 mapas.

Stern, C.R.; Navarro, X.; Muñoz, J. 2002. Obsidiana gris translúcida del volcán Chaitén en los sitios arqueológicos de Quilo (Isla Grande de Chiloé) y Chanchán (X Región), Chile, y obsidiana del Mioceno in Chiloé. Anales del Instituto de la Patagonia 30: 167-174.

Taylor, John R. 1997. An Introduction to Error Analysis: The study of uncertainties in physical measurements. Second edition. University Science Books, Sausalito, CA: $327 \mathrm{p}$.

Valenzuela, C. 2011. Tasa de crecimiento del complejo de domos del volcán Chaitén, periodo Mayo 2008 -Diciembre 2009. Thesis (Unpublished), Universidad de Chile: 57 p.

Wadge, G.; Mattioli, G.S.; Herd, R.A. 2006. Ground deformation at Soufrière Hills Volcano, Montserrat during 1998-2000 measured by radar interferometry and GPS. Journal of Volcanology and Geothermal Research 152 (1-2): 157-173.

Walter, T.R.; Wang, R.; Acocella, V.; Neri, M.; Grosser, H.; Zschau, J. 2009. Simultaneous magma and gas eruptions at three volcanoes in southern Italy: An earthquake trigger? Geology 37: 251-254.

Wang, K.; Hu, Y.; Bevis, M.; Kendrick, E.; Smalley, Jr. R.; Vargas, R.B.; Lauría, E. 2007. Crustal motion in the zone of the 1960 Chile earthquake: Detangling earthquake-cycle deformation and forearc-sliver 
translation, Geochemistry, Geophysics, Geosystems 8 (10): 14 p. doi: 10.1029/2007GC001721.

Watt, S.F.L.; Pyle, D.M.; Mather, T.A.; Martin, R.S.; Matthews, N.E. 2009. Fallout and distribution of volcanic ash over Argentina following the May 2008 explosive eruption of Chaitén, Chile. Journal of Geophysical Research 114 (B04207) doi: 10.1029/ 2008JB006219.

Watt, S.F.L.; Pyle, D.M.; Mather, T.A. 2013. Evidence of mid- to late-Holocene explosive rhyolitic erup- tions from Chaitén Volcano, Chile. Andean Geology 40 (2): 216-226.

Wicks, C.; de la Llera, J.C.; Lara, L.E.; Lowenstern, J. 2011. The role of dyking and fault control in the rapid onset of eruption at Chaitén Volcano, Chile. Nature 478: 374-377.

Wright, R.; Flynn, L.P.; Garbeil, H.; Harris, A.J.L.; Pilger, E. 2004. MODVOLC: near-real-time thermal monitoring of global volcanism. Journal of Volcanology and Geothermal Research 135: 29-49.

Manuscript received: November 11, 2012; revised/accepted: April 04, 2013; available online: April 09, 2013. 